\title{
DIURNAL VARIATION IN TRANSPIRATION IN RICE AND WHEAT PLANTS GROWN IN SAND AND SANDY SOIL UNDER CHANNEL IRRIGATION SYSTEM
}

\author{
MD. Khalilur RahMAN* \\ Department of Soil, Water and Environment, University of Dhaka, Dhaka 1000, Bangladesh
}

Key words: Diurnal variation, Sandy soil, Transpiration loss

\begin{abstract}
Transpiration loss of water of rice and wheat plants at different times of the day grown in sand and sandy soil in specially design earthen pots was studied. The highest plateau of transpiration loss was observed at 14:30 hour for both the crops. The results did not vary significantly $(p=0.05)$.
\end{abstract}

Transpiration involves continuous movement of water from the roots, through the stem and lost through the leaves to the atmosphere. Water is an important factor with respect to plant survival in wetland and dry landscape ${ }^{(1,2)}$. Under unsaturated condition total transpiration was about three times more than that of saturated condition in species of Cassia tora L. and Cassia occidentalis L.(3). The water relation of the plants is evaluated by determining the relative water content (RWC) of leaves ${ }^{(4)}$. RWC of leaves indicate water status of plants which in turn regulates transpiration, eco-physiological activities, stomatal aperture and reflect the ability of the plant to absorb water. Irrigation accuracy depends mainly on correct estimates of crop evapotranspiration, available soil water and soil types. The Charland farmers in the Teesta and Dharala river basin area of Lalmonirhat district grow pumpkin abundantly on sandy land to alleviate poverty. But irrigation is a great problem due to high percolation rate of this sand-dominated land.

The objective of the present experiment was to assess the transpiration loss of water of rice and wheat plants grown in sand and sandy soil under channel irrigation system. The experiment was carried out in specially designed earthen pots. Pots were arranged in a completely randomized block design. The size of the pot was $38 \mathrm{~cm} \times 27 \mathrm{~cm} \times 21 \mathrm{~cm}$. A $5 \mathrm{~cm}$ wide irrigation channel passing laterally and extending up to the bottom of the box bifurcated the box into two compartments. Each compartment had a capacity for $6.4 \mathrm{~kg}$ of sand or soil. The slits were provided with nylon gauze and the plant roots were allowed to pass through the nylon gauze of slits into the irrigation channel. Sand and soil had a moisture at field capacity of 15.35 and $22.15 \%$, respectively. The soil being sandy loam in texture and had a $\mathrm{pH}$ of 7.2 , organic carbon $0.62 \%$, CEC $7.16 \mathrm{meq} / 100 \mathrm{~g}$ soil, available NPK were 85,4 and $120 \mathrm{mg} / \mathrm{kg}$ and total NPK were $0.08,0.03$ and $0.72 \%$, respectively.

*E- mail: <khali193@du.ac.bd>. 
Nitrogen as urea at the rate of $111 \mathrm{~kg} / \mathrm{ha}$, phosphorus as TSP at the rate of $84 \mathrm{~kg} / \mathrm{ha}$, and potassium as $\mathrm{MP}$ at the rate of $84 \mathrm{~kg} / \mathrm{ha}$ and nutrient salts of calcium nitrate $\mathrm{Ca}\left(\mathrm{NO}_{3}\right)_{2}$, magnesium sulphate $\mathrm{MgSO}_{4} .7 \mathrm{H}_{2} \mathrm{O}$, copper sulphate $\mathrm{CuSO}_{4} .5 \mathrm{H}_{2} \mathrm{O}$, manganous sulphate $\mathrm{MnSO}_{4} . \mathrm{H}_{2} \mathrm{O}$, zinc sulphate $\mathrm{ZnSO}_{4} .7 \mathrm{H}_{2} \mathrm{O}$, boric acid $\mathrm{H}_{3} \mathrm{BO}_{3}$, ammonium molybdate $\left(\mathrm{NH}_{4}\right)_{6} \mathrm{Mo}_{7} \mathrm{O}_{24} \cdot \mathrm{H}_{2} \mathrm{O}$ and Fe-citrate were applied in the form of solution to the irrigation channel only.

Table 1. Diurnal changes in transpiration loss of water of rice and wheat plants grown in sand and sandy soil under channel irrigation system.

\begin{tabular}{|c|c|c|c|c|c|c|c|c|}
\hline Treatments & & & ate of $\operatorname{tr}$ & nspiratic & / hour) & t day ti & & \\
\hline & & & & Hou & & & & \\
\hline & $06: 30$ & 08:30 & $10: 30$ & $12: 30$ & $14: 30$ & $16: 30$ & $18: 30$ & \\
\hline Rice & & & Los & $\begin{array}{l}\text { of water } \\
(\mathrm{g} / \mathrm{h})\end{array}$ & & & & $\begin{array}{c}\text { Total loss } \\
\text { (g) }\end{array}$ \\
\hline Sand & - & $\begin{array}{l}20.5 \\
\pm 1.76\end{array}$ & $\begin{array}{l}27.5 \\
\pm 2.13\end{array}$ & $\begin{array}{c}35.0 \\
\pm 2.04\end{array}$ & $\begin{array}{l}39.5 \\
\pm 2.47\end{array}$ & $\begin{array}{l}31.5 \\
\pm 2.43\end{array}$ & $\begin{array}{l}24.0 \\
\pm 1.98\end{array}$ & 178 \\
\hline Sandy soil & - & $\begin{array}{c}21.5 \\
\pm 1.55\end{array}$ & $\begin{array}{l}30.5 \\
\pm 1.92\end{array}$ & $\begin{array}{l}38.0 \\
\pm 2.10\end{array}$ & $\begin{array}{l}45.0 \\
\pm 2.53\end{array}$ & $\begin{array}{l}37.0 \\
\pm 2.24\end{array}$ & $\begin{array}{l}28.5 \\
\pm 1.65\end{array}$ & 200.5 \\
\hline Wheat & & & & & & & & \\
\hline Sand & - & $\begin{array}{l}20.0 \\
\pm 1.41\end{array}$ & $\begin{array}{l}28.5 \\
\pm 2.19\end{array}$ & $\begin{array}{l}37.0 \\
\pm 2.62\end{array}$ & $\begin{array}{l}42.5 \\
\pm 2.64\end{array}$ & $\begin{array}{l}35.0 \\
\pm 2.55\end{array}$ & $\begin{array}{l}25.5 \\
\pm 2.24\end{array}$ & 188.5 \\
\hline Sandy soil & - & $\begin{array}{l}18.0 \\
\pm 2.24\end{array}$ & $\begin{array}{l}25.5 \\
\pm 2.47\end{array}$ & $\begin{array}{l}33.0 \\
\pm 2.68\end{array}$ & $\begin{array}{l}39.0 \\
\pm 3.21\end{array}$ & $\begin{array}{l}30.5 \\
\pm 2.61\end{array}$ & $\begin{array}{l}23.5 \\
\pm 2.43\end{array}$ & 169.5 \\
\hline
\end{tabular}

$\pm=$ Standard deviation.

Rice (three seedlings BR3) and wheat (three seeds of LV Sonalika) plants were grown in sand and sandy soil media at the two sides of the irrigation channel and substantial amount of roots passed into the channel through nylon gauze in search of water. Water was supplied and preserved in the channel instead of supplying to the sand and sandy soil media. The roots absorbed water directly from the irrigation channel. To prevent evaporation losses of water from the irrigation channel a light closing device was placed at the top of the channel. In a sunny day, transpiration loss was measured at 06:30, 08:30, 10:30, 12:30,14:30, 16:30 and 18:30 hours of the day at flowering stage by weighing the pots at regular intervals (two hours) in a large scale top balance. During this measurement, evaporation from the rooting medium was prevented by enclosing the pots with large polythene bags which were sealed carefully around the stem of the plants. Results shown are the mean of three replicates (Table 1). Loss of water by transpiration for rice at 08:30 hour was 20.5 and $21.5 \mathrm{~g}$ and progressively increased up to 14:30 hour and the values were 39.5 and $45 \mathrm{~g} / \mathrm{h}$, respectively. The total loss of water at 
daylight hours was 178 and $200.5 \mathrm{~g}$ in sand and sandy soil, respectively (Table 1). For wheat plants, the transpiration loss of water at $08: 30$ hour was 20 and $18 \mathrm{~g} / \mathrm{h}$ and progressively increased up to $14: 30$ hour and the values were 42.5 and $39 \mathrm{~g} / \mathrm{h}$ in sand and sandy soil, respectively. The total loss of water was 188.5 and $169.5 \mathrm{~g}$ in sand and sandy soil, respectively (Table 1). Transpiration loss of water increased from morning till noon and then decreased towards evening in both the media for both crops. The highest plateau of transpiration loss was observed at 14:30 hour. Transpiration increased gradually due to increasing temperature which probably brought out the changes in the physiological characteristics for both crops. Loss of water for rice was higher in sandy soil than sand and it was reverse in case of wheat. Transpiration was higher in rice plants grown in sandy soil which was an indication of high uptake of water and nutrients from irrigation channel (Table 1$)$. The results did not vary significantly $(p=0.05)$. Growth and leaf area were also found higher in sandy soil media. Lawson and Jenik ${ }^{(5)}$ suggested that transpiration rates were more influenced by factors related to water supply than by factors connected with drought avoidance. Wang et al. (6) found that the effect of water, heat and atmospheric pollutants on transpiration of urban trees exerted only minor effect on transpiration as compared to other environmental factors.

Transpiration was higher in wheat plants grown in sand (Table 1). It might be due to efficient utilization of water and nutrients from irrigation channel. The results showed no significant $(\mathrm{p}=0.05)$ variation. Growth and leaf area were higher in sand. Leaf area is an important variable for most eco-physiological studies in terrestrial ecosystems for elucidating competition among different plant species concerning light interception, photosynthetic efficiency, fertilizer, irrigation response, evapotranspiration, plant growth, yield potential(7). Effects of tannery effluent on leaf characters, leaf pigments and rate of transpiration in the seedlings of six tree species were investigated in pot culture. The number of stomata, leaf pigment and transpiration rate of the tree seedlings were also affected due to tannery effluent stress ${ }^{(8)}$. The rate of growth of plant cells and the efficiency of their physiological processes are highest when the cells are at maximum turgor. The rate of water loss varies with daily environmental conditions, such as humidity and temperature, and with the characteristics of plants( ${ }^{(9)}$.

Thus, the transpiration loss values indicated that the degree of turgidity of plants was dependent on continuous supply of water and nutrient solution to the roots from irrigation channel irrespective of sand and sandy soil media. This system of irrigation will perform better in sand-dominated specially charland cultivation of Bangladesh in winter season.

\section{References}

1. Nazrul-Islam AKM 1983. Tissue water relation in a range of plant species and its ecological significance. Flora 174: 329- 337. 
2. Nazrul-Islam AKM and AKMM Alam 1986. Comparative study of water relation in two cultivars of jute under waterlogged and non-waterlogged conditions. Geobios 134: 174177.

3. Nazrul-Islam AKM and S Begum 2012. Autecology of selected plant species. Physiol. Ecol. \& Environ. Sci. 3: 35- 42.

4. Rahman MK, SMA Faiz and IU Ahmed 1994. Diurnal variation in the water content of the leaf of rice plants grown in sand and sandy soil under irrigation. J. Asiat. Soc. Bangladesh, Sci. 20: 93- 97.

5. Lawson GW and J Jenik 1967. Observations on microclimate and vegetation interrelationships on the Accra Plains (Ghana). J. Ecol. 55: 773- 785.

6. Wang H, Z Ouyang, W Chen, X Wang, H Zheng and Y Ren 2011. Water, heat and airborne pollutants effects on transpiration of urban trees. Environ. Pollution 159: 2127- 2137.

7. Williams LE 1987. Growth of "Thompson Seedless" grapevines. I. Leaf area development and dry weight distribution. J. Amer. Soc. Hort. Sci. 112: 325- 330.

8. Alamgir ANM and MS Islam 2012. Effects of tannery effluent on growth, leaf characters and transpiration in seedlings of six tree species. Physiol. Ecol. \& Environ. Sci. 3: 13- 22.

9. Smith TM and RL Smith 2012. Element of Ecology. $6^{\text {th }}$ edition, Pearson Education. Inc. and Dorling Kindersley (India) Pvt. Ltd. pp.719.

(Manuscript received on 18 March, 2015; revised on 5 June, 2015) 